\title{
The use of targeted selective treatments on controlling gastrointestinal nematodes in different sheep categories under grazing system ${ }^{1}$
}

\author{
Carlo A.T. Marques ${ }^{3}$, Luana A. Saraiva ${ }^{2}$, Jacira N.C. Torreão ${ }^{3}$, Tairon P.D. Silva ${ }^{4 *}$, \\ Leílson R. Bezerra², Ricardo L. Edvan², Marcos J. Araújo² \\ and Romilda R. Nascimento ${ }^{2}$
}

\begin{abstract}
Marques C.A.T., Saraiva L.A., Torreão J.N.C., Silva T.P.D., Bezerra L.R., Edvan R.L., Araújo M.J. \& Nascimento R.R. 2018. The use of targeted selective treatments on controlling gastrointestinal nematodes in different sheep categories under grazing system. Pesquisa Veterinária Brasileira 38(3):470-476. Departamento de Zootecnia, Universidade Federal do Piauí, Bom Jesus, Piauí, PI 64900-000, Brazil. E-mail: tairon.mvet@gmail.com

Infections with gastrointestinal nematodes can impair both the animal health and performance. Thereby, the aim of this study was to evaluate the use of targeted selective treatments as the FAMACHA ${ }^{\oplus}$ system and faecal egg count on controlling gastrointestinal nematodes in different sheep categories under grazing system. Thirty Santa Inês sheep, six in each category (six weaning, six weaned lambs, six non-pregnant ewes, six pregnant ewes and six lactating ewes were used. Sheep were weighed, and blood and faecal samples were collected on day $0,15,30,45,60$ and 75 for determination of faecal egg count (FEC), packed cell volume (PCV), total plasma protein (PPT) and the mucosa colour by FAMACHA ${ }^{\odot}$ system in the morning (1) and afternoon (2). The faecal egg count was higher $(p=0.0039)$ in weaning and weaned lambs compared to the non-pregnant, pregnant and lactating ewes. Also, FEC differed between ewes with higher counts in lactating ewes. The observation of eye mucosae showed a frequency of $100 \%$ of FAMACHA ${ }^{\odot}$ scores ranged of 2.45 to 2.91 in the morning, differing ( $p=0.0494)$ among the categories, where weaned lambs showed better score. The animal categories and period interaction had a significant $(p=0.0148)$ effect on FAMACHA $^{\odot}$ score 1 with better score in weaned lambs compared to the pregnant ewes at day 0,15 and 75. In addition, weaned lambs were presented better FAMACHA ${ }^{\odot}$ score compared with weaning lambs and lactating ewes at day 45 than weaning lambs at day 60 and 75. Packed cell volume in the morning and in the afternoon was influenced by days of collection with lower percentage at 30 days of experiment. The FAMACHA ${ }^{\oplus}$ system seems to be a suitable method to detect parasite infections. However, use of all available methods increases the accuracy of the diagnosis and promotes better control of gastrointestinal nematodes in grazing sheep.

INDEX TERMS: Selective treatments, gastrointestinal, nematodes, sheep, grazing system, animal category, eye color, total plasma protein, verminoses.
\end{abstract}

\footnotetext{
${ }^{1}$ Received on October 1, 2016.

Accepted for publication on October 18, 2016.

${ }^{2}$ Departamento de Zootecnia, Universidade Federal do Piauí (UFPI), Bom Jesus, Piauí, PI 64900-000, Brazil.

${ }^{3}$ Universidade Federal de Sergipe, Campus Sertão, Rodovia Engenheiro Jorge Neto Km 3, Campus Nossa Senhora da Glória, Sergipe, SE 49680-000, Brazil.

${ }^{4}$ Laboratório de Nutrição Animal, Centro de Energia Nuclear na Agricultura, Universidade de São Paulo, Av. Centenário 303, Piracicaba, São Paulo, SP 13425-970, Brazil. *Corresponding author: tairon.mvet@gmail.com
}

RESUMO.- [O uso de tratamentos seletivos no controle de nematóides gastrointestinais em diferentes categorias de ovinos sob sistema de pastejo.] Infecções por nematóides gastrointestinais podem prejudicar tanto a saúde como o desempenho animal. Diante disso, objetivou avaliar o uso de tratamentos seletivos como o sistema FAMACHA ${ }^{\odot}$ e a contagem de ovos por grama de fezes no controle de nematóides gastrointestinais em diferentes categorias de 
ovinos sob sistema de pastejo. Trinta ovelhas Santa Inês, seis em cada categoria (seis cordeiros lactentes, seis cordeiros desmamados, seis ovelhas não-prenhes, seis ovelhas prenhes e seis ovelhas lactantes) foram utilizadas. Os ovinos foram pesados, amostras de sangue e fezes foram coletadas nos dias $0,15,30,45,60,75$ para determinação de ovos por grama de fezes (OPG), volume globular (VG), proteínas plasmáticas totais (PPT) e avaliação da mucosa ocular pelo sistema FAMACHA $^{\odot}$ pela manhã (1) e pela tarde (2). A contagem de ovos por grama de fezes foi maior $(p=0,0039)$ nos cordeiros lactentes e desmamados comparado às ovelhas não prenhes, prenhes e lactantes. Também o OPG diferiu entre ovelhas com maior contagem em ovelhas lactantes. A observação da mucosa ocular mostrou que a frequência do escore FAMACHA ${ }^{\odot}$ variou de 2,45 a 2,91 pela manhã, diferindo $(p=0,0494)$ entre categorias, aonde cordeiros desmamados mostraram melhor escore. A interação categoria animal e período teve um efeito significante no escore FAMACHA ${ }^{\circledR} 1$ com melhor escore em cordeiros desmamados comparado às ovelhas prenhes nos dias 0,15 e 75. Além disso, cordeiros desmamados apresentaram melhor escore FAMACHA ${ }^{\oplus}$ comparado com os cordeiros lactentes e ovelhas lactantes aos 45 dias e com cordeiros lactentes nos dias 60 e 75 . 0 volume globular pela manhã e pela tarde foi influenciado pelos dias de coleta com menor porcentagem aos 30 dias de experimento. O Sistema FAMACHA ${ }^{\odot}$ mostrou ser um método eficaz para detectar infecções parasitárias. Contudo, o uso de todos os métodos disponíveis aumenta a acurácia do diagnóstico e promove melhor controle de nematóides gastrointestinais em sistemas de pastejo.

TERMOS DE INDEXAÇÃO: Tratamentos seletivos, nematoides, gastrointestinal, ovinos, pastejo, categoria animal, mucosa ocular, proteínas plasmáticas totais, verminoses.

\section{INTRODUCTION}

Infections with gastrointestinal nematodes (GIN) can impair both the animal health and performance. The different degrees of infection to which the animals are exposed may cause low productivity of adult animals with high mortality and delayed corporal development of young, reducing the off-take rate and it has been the main cause for losses of production in small ruminant production system (Molento 2009). Some factors such as age, nutritional and physiological status (pregnancy and lactation) may contribute to determining the prevalence of gastrointestinal nematodes in the host being essential to production system.

The control of these gastro-intestinal infections relies heavily on the administration of anthelminthic drugs. However, due to their intensive use with increased number of studies report on the development of anthelmintic resistance in parasitic nematodes of ruminants (Torres-Acosta et al. 2012, Vlaminck et al. 2015). Parasitic resistance was described since the 1990s and many new reports suggest that the Brazil situation is deteriorating effect (Almeida et al. 2010, Veríssimo et al. 2012). Hence, anthelmintics were needed to be used carefully to increase the productive and reproductive performance of animals.
To better parasitic control and to reduce the use of anthelmintic some strategies have been proposed: biological control (Waller 2006), cooper oxide needles (Vatta et al. 2009), medicinal plants (Sawleha et al. 2010), vaccination (Arunkumar et al. 2012) and the use of targeted selective treatments (TST) (Kenyon \& Jackson 2012, O'Shaughnessy et al. 2015, Mohammed et al. 2016). As per of our knowledge, one of the cutting-edge resources used to slow down the development of anthelmintic resistance is the FAMACHA ${ }^{\odot}$ system, a selective method useful for controlling gastrointestinal verminosis in small ruminants. By far the best-known example of a TST indicator is FAMACHA - an acronym derived from the name of the originator of the idea, Dr. Faffa Malan (FAffa MAlan CHArt) - a system developed in South Africa that uses anaemia, determined based on the colour of the lower eyelid mucous membrane in small ruminants (Vatta et al. 2001, Van Wyk \& Bath 2002). Although FAMACHA ${ }^{\odot}$ is a system of treating only animals with clinical signs and then reducing the chance of development of drug resistance, its usage is not practiced in many regions around the world.

Our hypothesis is that the FAMACHA ${ }^{\odot}$ system and faecal egg count can help in the reduction of anthelmintic resistance by treating animals only unable to survive with current nematodes species challenge on pasture. Thus, the aim of this study was to evaluate the use of targeted selective treatments as the FAMACHA ${ }^{\odot}$ system and faecal egg count on controlling gastrointestinal nematodes in different sheep categories under grazing system.

\section{MATERIALS AND METHODS}

Site of study. All animal procedures were conducted under experimental license (091/2010) from the Federal University of Piauí ethical committee. The experiment was carried out at Technical School of Bom Jesus, Federal University of Piauí (UFPI), Valley Gurguéia

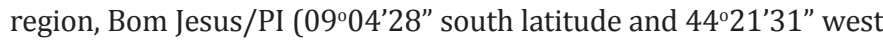
longitude) at an altitude of $277 \mathrm{~m}$ above sea level with a semiarid climate (Bsh), according to Köppen. The experiment was performed from April to June 2013.

Animals and technical details. Thirty Santa Inês sheep were used. All animals were maintained on grazing in pasture paddock of Andropogon grasses (Andropogon gayanus) with the additional concentrate supplementation at the rate of $1.0 \%$ body weight (BW) consisting of cracked corn (70\%), soybean meal (25\%) and mineral supplement (5\%), based on the dry matter was added (Table 1). Lambs had access to creep-fed until 90 days of age, when the lambs were weaned. The supplement concentrations were formulated according to the recommendations of the NRC (2007). All animals received anthelmintic treatment (Disophenol/dose according to manufacturer) 15 days before start of the study. the animal categories used were: six weaning lambs, six weaned lambs, six non-pregnant ewes, six pregnant ewes and six lactating ewes (details of each category in Table 2).

Body weight, body conditions core and fecal egg counting. Sheep were weighed and blood and faecal samples were collected on day $0,15,30,45,60$ and 75 in the morning. The body condition score (BCS) was evaluated at the moment of the weekly weighing according to the method described by Thompson \& Meyer (2006). The measurements were made on a scale from 1 to 5 (1=under-weight 
Table 1. Chemical composition of experimental ingredients, concentrate supplement and Andropogon gayanus

\begin{tabular}{|c|c|c|c|c|c|c|c|c|}
\hline \multirow{2}{*}{ Ingredients } & \multicolumn{8}{|c|}{ Chemical composition } \\
\hline & DM & $\mathrm{CP}$ & $\mathrm{EE}$ & TDN & NDF & $\mathrm{ADF}$ & $\mathrm{Ca}$ & $\mathrm{P}$ \\
\hline Corn meal & 87.19 & 9.98 & 5.19 & 67.50 & 24.55 & 5.87 & 0.05 & 0.49 \\
\hline Soybean meal & 88.48 & 48.76 & 1.75 & 80.73 & 15.37 & 9.64 & 0.33 & 0.57 \\
\hline${ }^{1}$ Mineral mixture & 97.91 & - & - & - & - & - & 18.00 & 13.00 \\
\hline Supplement & 88.04 & 19.17 & 4.06 & 67.43 & 21.02 & 6.51 & 0.90 & 1.13 \\
\hline Andropogon & 27.45 & 7.50 & 2.02 & 53.56 & 74.70 & 41.97 & 0.33 & 0.11 \\
\hline
\end{tabular}

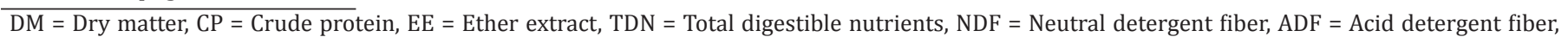

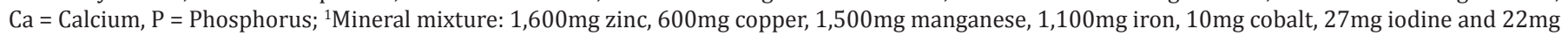
selenium. 1,000g.

Table 2. Constitution of the experimental groups for the evaluation of controlling gastrointestinal nematodes in different categories of Santa Inês sheep

\begin{tabular}{ccl}
\hline Group & N & \multicolumn{1}{c}{ Constitution of the experimental groups } \\
\hline I & 6 & Weaning lambs: lambs from birth until 3 months old. \\
II & 6 & Weaned lambs: lambs with 3-6 months old. \\
III & 6 & Non-pregnant ewes \\
IV & 6 & $\begin{array}{l}\text { Pregnant ewes: pregnant females with over } 120 \text { days of } \\
\text { gestation. }\end{array}$ \\
V & 6 & Lactating ewes: females up to 30 days postpartum.
\end{tabular}

and $5=$ overweight). Individual sheep faecal egg count (FEC) was determined from rectal faecal samples using a modified technical by Whitlock (1948). The FEC was considered as a quantitative indicator of infestation and prior to the analyses, the values were $\log$ transformed [using $\log (\mathrm{x}+1)$ ] to stabilize the variance. All data were back transformed as geometric means.

Blood collection and mucosa colour recording. Blood samples were collected at 7:00 and 14:00 h by jugular venipuncture using needles coupled to vacutainer tubes containing $0.05 \mathrm{ml}$ of a $10 \%$ aqueous solution of ethylene diamine tetra acetic acid (EDTA) per $5 \mathrm{ml}$ of blood. The blood samples were kept in a cooler with ice (temperature between 2 and $8^{\circ} \mathrm{C}$ ) until they were transported to the Clinical Pathology Laboratory (CPCE-UFPI), where the packed cell volume (PCV) and total plasma protein (PPT) both morning (2) and afternoon (2) were determined. The packed cell volume was determined with the micro hematocrit technique by using homogeneous capillary tubes of $75 \mathrm{~mm}$ in length and one millimeter in diameter. The determination of total plasma protein (TPP) was performed by refractometry after the blood was centrifuged in micro hematocrit capillary tubes. The mucosa colour was recorded (also, in the morning (1) and afternoon (2)) once by the FAMACHA ${ }^{\odot}$ method by dividing the colour into five different colour levels (Vatta et al. 2001): 1 = red, non-anemic; 2 = red-pink, non-anemic; 3 = pink, mildly anemic; 4 = pink-white, anemic; 5 = white, severely anemic. During the entire study period, the clinical evaluation was made by the same veterinarian investigator.

Statistical analysis. The statistical analysis was performed using SAS v. 9.3 ${ }^{\circledR}$ software (SAS Institute Inc., Cary, North Carolina, USA). The results were submitted to analysis of variance in a MIXED procedure with measures repeated over time. Animal category, experimental days and animal category x period interaction were used as fixed effects and animal as subject. Means were compared with Tukey test at 5\% probability. The covariance structure that better adjust to data was chosen according to the lowest AICC and BIC.

Factor analysis (FACTOR procedure) and CORR procedure were performed to verify the relationship between thermal variables and physiological responses over time. The factor analysis performs a variety of common factor and component analyses with measures carried out using as multivariate data. The first two factors that explained the greater proportion of data variation were selected and results of the factors show the relationship between the variables in the study

\section{RESULTS}

\section{General results}

General results of the analyses of variance are shown in Table 3. We found significant effect of animal category on all traits. FAMACHA ${ }^{\odot}$ score 1 , packed cell volume 1 and 2 were influenced by period of the day. However, only FAMACHA ${ }^{\odot}$ score 1 was affected by animal categories x period interaction.

\section{Body condition score}

The body condition score (BCS), FEC, FAMACHA ${ }^{\oplus}$ scores, packed cell volume and total plasma protein observed in the different categories of sheep during the study period were reported in Table 4 . The BCS in non-pregnant, pregnant and lactating ewes were differed $(p<0.0001)$, whereas ewes in lactation presented higher mobilization of body reserves.

\section{Fecal egg count}

The fecal egg count was higher $(p=0.0039)$ in weaning and weaned lambs compared to the non-pregnant, pregnant and lactating ewes. Also, FEC differed between ewes with higher counts in lactating ewes. The observation of eye mucosa showed a frequency of $100 \%$ of FAMACHA $^{\odot}$ scores ranged of 2.45 to 2.91 in the morning with different ( $p=0.0494)$ among the categories, whereas weaned lambs had showed better score. FAMACHA ${ }^{\odot}$ score in the afternoon were same among the categories. Differences were found among the categories in packed cell volume 1 and 2, with lower volume in weaned lambs (28.45 \pm 0.84$)$ and lactating ewes $(27.63 \pm 0.81)$ compared to other Groups. Levels of total plasma protein had showed significant difference among the categories in morning and afternoon period. Greater values were found in ewes (non-pregnant, pregnant and in lactation). However, weaning lambs showed values above than the standards. 


\section{Mucosa colour by FAMACHA ${ }^{\odot}$ score}

The animal categories $x$ period interaction had a significant $(p=0.0148)$ effect on FAMACHA $^{\odot}$ score 1 with lower score in weaned lambs (1.8) compared to the pregnant ewes at day 0,15 and 75 (3.2,3.2 and 3.3, respectively). Also, weaned lambs were better FAMACHA ${ }^{\oplus}$ score compared with weaning lambs (3.2) and lactating ewes (3.3) at day 45 than weaning lambs at day 60 (3.3) and 75 (3.5) (Fig.1). Packed cell volume in the morning and in the afternoon was influenced by days of collection with lower percentage at 30 days of experiment (Fig.2).

\section{Correlations and factor analysis}

Positive correlation was obtained between the body weight (BW) and Body condition score (BCS) (Table 4 and 5). In addition, we found positive correlation between BW and FC, whereas negative correlation between FEC and TPP.

First factor indicates a positive correlation among BCS, BW and PCV. According to second factor, it was possible to observe that had a negative correlation between fecal egg count and total plasma protein (Fig.3).

Table 3. Determinative coefficients of significant level of fixed factors and their interactions obtained from analysis of variance with all studied variables

\begin{tabular}{lcccccccccc}
\hline \multicolumn{1}{c}{ Effects } & BW & BCS & FEC & FAM1 & FAM2 & PCV1 & PCV2 & TPP1 & TPP2 \\
\hline Animal category & $<.0001$ & $<.0001$ & 0.0211 & 0.0228 & 0.0260 & 0.0467 & 0.0414 & $<.0001$ & $<.0001$ \\
Days of collection (period) & 0.1874 & 0.0570 & 0.2947 & 0.0038 & 0.4838 & 0.0025 & 0.0038 & 0.0779 & 0.1791 \\
Animal category - period & 0.8910 & 0.4132 & 0.8633 & 0.0148 & 0.7760 & 0.6065 & 0.9923 & 0.5589 & 0.1957
\end{tabular}

BW = Body weight, $\mathrm{BCS}=$ Body condition score, FEC = Fecal egg count, FAM $1=$ Famacha in the morning, FAM $2=$ Famacha in the afternoon, PCV 1 = Packed cell volume in the morning, PCV $2=$ Packed cell volume in the afternoon, TPP $1=$ Total plasma protein in the morning, TPP $2=$ Total plasma protein in the afternoon.

Table 4. Means \pm SE of FAMACHA ${ }^{\odot}$ score, fecal egg count (FEC), packed cell volume (PCV), total plasma protein (TPP), body weight (BW) and body condition score (BCS) in different animal category of Santa Inês sheep

\begin{tabular}{|c|c|c|c|c|c|c|}
\hline Variable & Weaning lambs & Weaned lambs & Non-pregnant ewes & Pregnant ewes & Lactating ewes & P value \\
\hline Body weight $(\mathrm{kg})$ & $12.88 \pm 1.58 \mathrm{~d}$ & $21.38 \pm 1.58 \mathrm{c}$ & $52.67 \pm 129 \mathrm{a}$ & $47.20 \pm 1.29 b$ & $44.60 \pm 1.52 b$ & $<.0001$ \\
\hline Body condition score & --- & --- & $2.87 \pm 0.11 \mathrm{a}$ & $2.48 \pm 0.11 \mathrm{a}$ & $2.00 \pm 0.13 b$ & $<.0001$ \\
\hline Fecal egg count & $2725.0 \pm 0.20 \mathrm{a}$ & $2229.2 \pm 0.20 \mathrm{a}$ & $225.0 \pm 0.16 c$ & $263.9 \pm 0.16 c$ & $983.3 \pm 0.19 b$ & 0.0211 \\
\hline Famacha score $1(1-5)$ & $2.75 \pm 0.13 a$ & $2.45 \pm 0.13 \mathrm{~b}$ & $2.80 \pm 0.10 \mathrm{a}$ & $2.91 \pm 0.10 \mathrm{a}$ & $2.88 \pm 0.12 \mathrm{a}$ & 0.0228 \\
\hline Famacha score 2 (1-5) & $2.70 \pm 0.13$ & $2.70 \pm 0.13$ & $2.88 \pm 0.10$ & $2.94 \pm 0.10$ & $2.80 \pm 0.12$ & 0.3260 \\
\hline Packed cell volume $1(\%)$ & $30.04 \pm 0.84 a$ & $28.45 \pm 0.84 b$ & $30.25 \pm 0.68 a$ & $30.16 \pm 0.68 a$ & $27.63 \pm 0.81 b$ & 0.0467 \\
\hline Total plasma protein $2(\mathrm{~g} / \mathrm{dL})$ & $5.62 \pm 0.11 \mathrm{c}$ & $6.12 \pm 0.11 \mathrm{~b}$ & $6.90 \pm 0.09 \mathrm{a}$ & $6.85 \pm 0.09 \mathrm{a}$ & $6.30 \pm 0.10 \mathrm{~b}$ & $<.0001$ \\
\hline
\end{tabular}

Different letters at same rows and at the same columns indicate difference from Tukey test at $5 \%$ probability; $1=$ in the morning, $2=$ in the afternoon.

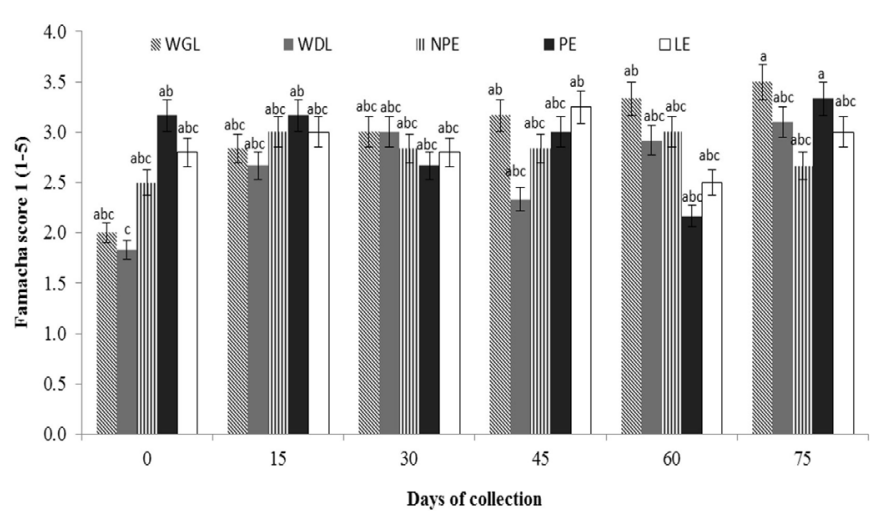

Fig.1. Animal category x period interaction on FAMACHA ${ }^{\odot}$ score in the afternoon of sheep in grazing sheep. Time points between each animal category with different letters are significantly different $(\mathrm{P}<0.05)$. WGL $=$ Weaning lambs, WDL $=$ Weaned lambs, NPE = Non-pregnant ewes, PE = Pregnant ewes, $\mathrm{LE}=$ Lactating ewes.

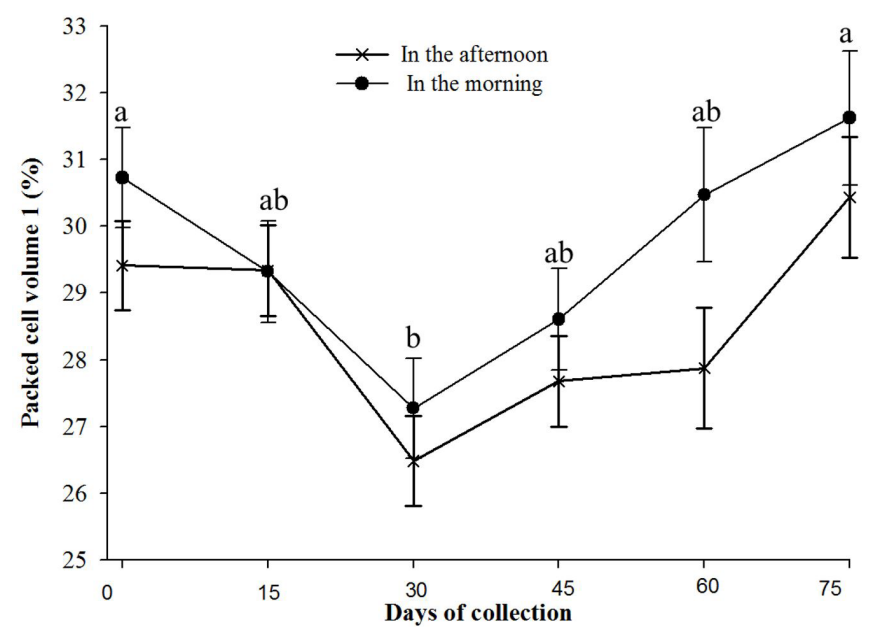

Fig.2. Mean $( \pm \mathrm{SE})$ values of packed cell volume of sheep in grazing sheep. Time points between each day of collection with different letters are significantly different $(\mathrm{P}<0.05)$. 
Table 5. Correlation coefficients among evaluated variables in different animal category of Santa Inês sheep

\begin{tabular}{|c|c|c|c|c|c|c|c|c|}
\hline & BW & BCS & FEC & FAM 1 & FAM 2 & PCV 1 & PCV 2 & TPP1 \\
\hline BCS & $0.426^{*}$ & & & & & & & \\
\hline FEC & $-0.288^{* *}$ & $0.032 \mathrm{~ns}$ & & & & & & \\
\hline FAM 1 & $0.174^{* *}$ & $0.051 \mathrm{~ns}$ & $-0.038 n s$ & & & & & \\
\hline FAM 2 & $0.0956 \mathrm{~ns}$ & $-0.230^{* *}$ & $0.002 \mathrm{~ns}$ & $0.304^{* *}$ & & & & \\
\hline PCV 1 & $0.109 \mathrm{~ns}$ & $0.195 \mathrm{~ns}$ & $-0.031 \mathrm{~ns}$ & $-0.439 * *$ & $-0.159 \mathrm{~ns}$ & & & \\
\hline PCV 2 & $0.069 \mathrm{~ns}$ & $0.321^{* *}$ & $-0.016 \mathrm{~ns}$ & $-0.135 n s$ & $-0.386^{* *}$ & $0.513^{*}$ & & \\
\hline TPP 1 & $0.587^{*}$ & $-0.027 \mathrm{~ns}$ & $-0.284^{* *}$ & $0.100 \mathrm{~ns}$ & $0.199 * *$ & $0.118 \mathrm{~ns}$ & 0.121 ns & \\
\hline TPP 2 & $0.523^{*}$ & $0.212^{* *}$ & $-0.261^{* *}$ & $0.105 \mathrm{~ns}$ & $0.188^{* *}$ & $0.119 \mathrm{~ns}$ & $0.202^{* *}$ & $0.835^{*}$ \\
\hline
\end{tabular}

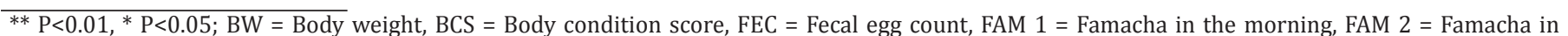

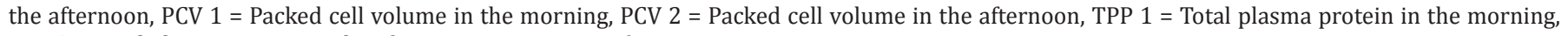
TPP 2 = Total plasma protein in the afternoon, ns = not significant.

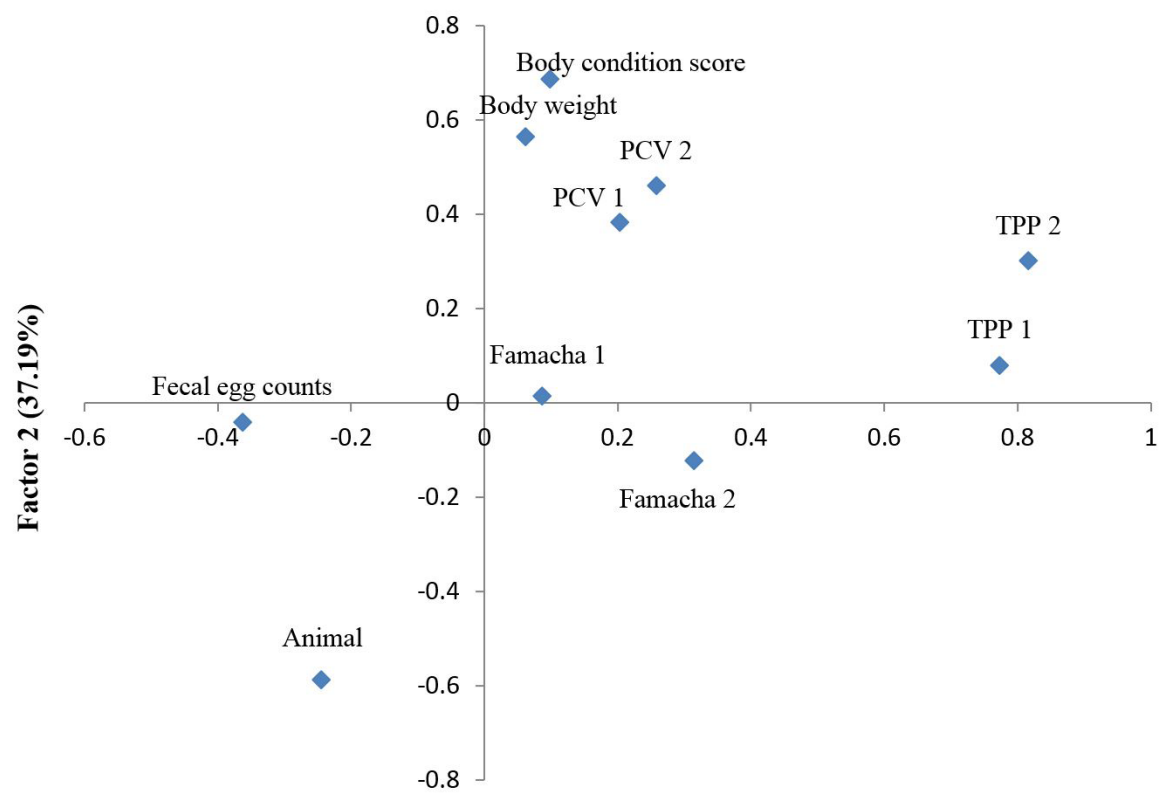

Factor $1(38.76 \%)$

Fig.3. Two first factors evaluating the FAMACHA ${ }^{\odot}$ system, FEC (fecal egg counts), PCV (packed cell volume), TPP (total plasma protein), BW (body weight) and BCS (body condition score) of Santa Inês sheep. The first two factors explained $75.95 \%$ of the variance between variables.

\section{DISCUSSION}

Lactating ewes had their body condition score influenced by milk production, this stage promotes lower BCS compared with non-pregnant and pregnant ewes due to depend on body fat mobilization. In lactating ewes, a negative energy balance is inevitable due to energy requirements of the ewes with increases more rapidly than the energy intake from the diet.

Gastrointestinal nematodes may affect selected animal categories in present experiment. However, the problem is most severe in young animals and females in the peripartum period. Young animals due to their immune system have undeveloped the ability to combat heavy infections. These results were found in our present study, whereas weaning and weaned lambs presented higher fecal egg count compared with the ewes. The degree of infection of lambs can vary depending of management conditions and the level of contamination of the pasture. Our results showed weaning lambs with higher fecal egg count corroborating with Rocha et al. (2005). Among ewes, lactating ewes showed higher values. This increase in elimination of eggs in early lactation period occurs due to "Spring rise" phenomenon or breaking of immunity in the peripartum (Barger 1993). This occurs because the organism directs nutrients for fetal growth and milk production during these stages, there is reduction in availability of nutrients to be used by the immune system to combat parasites (Almeida et al. 2012).

The observation of eye mucosae showed that $100 \%$ of animals presented FAMACHA ${ }^{\odot}$ scores less than 3 . Hence, it is confirmed that weaning lambs were resilient, because had a higher fecal egg count but FAMACHA ${ }^{\oplus}$ score did not differed of the ewes (non-pregnant, pregnant and in lactation) that presented lower fecal egg count. Resilience is defined as the ability of the host to resist anemia during a heavy infection period.

In the current study, use of FAMACHA ${ }^{\oplus}$ system and packed cell volume to identify resilient animals (the ability of an 
animal to withstand the effects of infection) in the different categories was more reliable than use of fecal egg count. This may be an indication that this population of Santa Inês sheep in semi-arid region raised in grazing is more resilient than resistant (Burke \& Miller 2008). Figure 2 describes the impact of verminosis on animal categories until 30 days of experimental period. However, after this period, the animals had the capacity of maintain the packed cell volume into the standard to the specie.

In the weaning lambs the heavy parasite load affected total plasma protein with values below standards corroborating with Amarante et al. (1999) and Rocha et al. (2005) who describe a negative relationship between PPT and EPG in sheep naturally infected by gastrointestinal nematodes. This result shows a higher susceptibility of young sheep and higher effect of gastrointestinal nematodes on lambs compared to ewes mainly due to incomplete development of the immune system.

The use of different strategies on control of gastrointestinal nematodes (FAMACHA ${ }^{\odot}$ system, clinical signs, body condition score and fecal egg count) was beneficial with evaluated in different sheep categories (Mohammed et al. 2016), showing a different response intra-herd, but a high ability of the animals against GIN (Molento 2009). Also, an early identification of high percentage of anemic animals, with high fecal egg count, lower PCV and TPP could represent an early therapeutic approach within the modern concept of targeted selective treatments (O'Shaughnessy et al. 2015) with a subsequent strategic and economic benefit (Di Loria et al. 2009).

According to the ewe categories, there was a body reserve mobilization with positive correlation between the body weight and Body condition score. However, lactating ewes were lower condition score and body weight due to higher nutritional requirements in this phase (milk production) (Scarpino et al. 2014, Silva et al. 2015). The animal categories with lower body weight (weaning lambs and weaned lambs) had a higher fecal egg count (Table 3) and this positive correlation may be explained due to these sheep category have incomplete developed of the immune system. In consequence of this higher fecal egg count the total plasma protein were decreased, mainly in the weaning lambs (more susceptible category). First factor indicates a positive correlation among BCS, BW and PCV. According to second factor, there was a negative correlation fecal egg count and total plasma protein (Fig.3). The factor analysis had showed positive effect of body weight on body condition score and packed cell volume indicating that a feeding management is essential to supply the nutritional requirements for animal health maintenance. However, if the management practices (mainly, nutritional requirements according to the animal categories and health management) is not supplied well, it may occur an increased in the prevalence of gastrointestinal nematodes (e.g. high fecal egg count and lower total plasma protein - showed in second factor) with direct effect on animal health.

\section{CONCLUSION}

FAMACHA $^{\odot}$ system seems to be a suitable method to detect parasite infections. However, the use of all available methods increases the accuracy of the diagnosis and promotes better control of gastrointestinal nematodes in grazing sheep.

\section{REFERENCES}

Almeida F.A., Garcia K.C.O.D., Torgerson P.R. \& Amarante A.F.T. 2010. Multiple resistance to anthelmintics by Haemonchus contortus and Trichostrongylus colubriformis in sheep in Brazil. Parasitol. Int. 59(4):622-625. http:// dx.doi.org/10.1016/j.parint.2010.09.006. PMid:20887800.

Almeida F.A.D., Sobrinho A.G.D.S., Endo V., Lima N.L.L., Columbeli A.C., Zeola N.M.B.L. \& Barbosa J.C. 2012. Gastrointestinal nematodes infection of primiparous and multiparous ewe in different reproductive stages. J. Anim. Prod. Adv. 2(8):373-378.

Amarante A.F.T., Craig T.M., Ramsey W.S., El-Sayed N.M., Desouki A.Y. \& Bazer F.W. 1999. Comparison of naturally acquired parasite burdens among Florida Native, Rambouillet and crossbreed ewes. Vet. Parasitol. 85(1):6169. http://dx.doi.org/10.1016/S0304-4017(99)00103-X. PMid:10447193.

ArunKumar S., AbdulBasith S. \& Gomathinayagam S. 2012. A comparative analysis on serum antibody levels of sheep immunized with crude extract and thiol-purified excretory/secretory antigen of Haemonchus contortus. Vet. World 5(5):279-284. http://dx.doi.org/10.5455/vetworld.2012.279-284.

Barger I.A. 1993. Influence of sex and reproductive status on susceptibility of ruminants to nematode parasitism. Int. J. Parasitol. 23(4):463-469. http:// dx.doi.org/10.1016/0020-7519(93)90034-V. PMid:8354597.

Burke J.M. \& Miller J.E. 2008. Use of FAMACHA system to evaluate gastrointestinal nematode resistance/resilience in offspring of stud rams. Vet. Parasitol. 153(1/2):85-92. http://dx.doi.org/10.1016/j.vetpar.2008.01.029. PMid:18314274.

Di Loria A., Veneziano V., Piantedosi D., Rinaldi L., Cortese L., Mezzino L., Cringoli G. \& Ciaramella P. 2009. Evaluation of the FAMACHA system for detecting the severity of anaemia in sheep from southern Italy. Vet. Parasitol.161(1/2):53-59. http://dx.doi.org/10.1016/j.vetpar.2008.12.002. PMid:19153013.

Kenyon F. \& Jackson F. 2012. Targeted flock/herd and individual ruminant treatment approaches. Vet. Parasitol. 186(1/2):10-17. http://dx.doi. org/10.1016/j.vetpar.2011.11.041. PMid:22188982.

Mohammed K., Abba Y., Ramli N.S.B., Marimuthu M., Omar M.A., Abdullah F.F.J., Sadiq M.A., Tijjani A., Chung E.L.T. \& Lila M.A.M. 2016. The use of FAMACHA in estimation of gastrointestinal nematodes and total worm burden in Damara and Barbados Black belly cross sheep. Trop. Anim. Health Prod. 48(5):1013-1020. http://dx.doi.org/10.1007/s11250-0161049-y. PMid:27038194.

Molento M.B. 2009. Parasite control in the age of drug resistance and changing agricultural practices. Vet. Parasitol. 163(3):229-234. http:// dx.doi.org/10.1016/j.vetpar.2009.06.007. PMid:19560869.

NRC 2007. Nutrient Requirements of Sheep: sheep, goats, cervids, and new world camelids. National Academic Press, Washington, D.C., USA. 384p.

O’Shaughnessy J., Earley B., Mee J.F., Doherty M.L., Crosson P., Barrett D. \& de Waal T. 2015. Controlling nematodes in dairy calves using targeted selective treatments. Vet. Parasitol. 209(3/4):221-228. http://dx.doi. org/10.1016/j.vetpar.2015.02.024. PMid:25770853.

Rocha R.A., Amarante A.F.T. \& Bricarello P.A. 2005. Resistance of Santa Inês and Ile de France suckling lambs to gastrointestinal nematode infections. Revta Bras. Parasitol. Vet. 14(1):17-20. PMid:16153339.

Sawleha Q., Dixit A.K. \& Dixit P. 2010. Use of medicinal plants to control Haemonchus contortus infection in small ruminants. Vet. World 3(11):515-518.

Scarpino F.B.O., Ezequiel J.M.B., Silva D.A.V. \& Van Cleef E.H.C.B. 2014. Óleo de soja e óleo de soja residual em dietas para ovinos confinados: parâmetros sanguíneos. Arch. Zootec. 63(241):207-210. http://dx.doi.org/10.4321/ S0004-05922014000100022.

Silva T.P.D., Marques C.A.T., Torreão J.N.C., Araújo M.J. \& Bezerra L.R. 2015. Intake, digestibility, milk yield and indicators of the metabolic status of native ewes fed supplemented diet under grazing system. Ital. J. Anim. Sci. 14(2):272-279. http://dx.doi.org/10.4081/ijas.2015.3738. 
Thompson J. \& Meyer H. 2006. Body condition scoring of sheep, p.28-31. Proc. 52nd Biennial Spooner Sheep Day, Madison, WI, USA.

Torres-Acosta J.F., Mendoza-de-Gives P., Aguilar-Caballero A.J. \& Cuéllar-Ordaz J.A. 2012. Anthelmintic resistance in sheep farms: update of the situation in the American continent. Vet. Parasitol. 189(1):89-96. http://dx.doi. org/10.1016/j.vetpar.2012.03.037. PMid:22520233.

Van Wyk J.A. \& Bath G.F. 2002. The FAMACHA system for managing haemonchosis in sheep and goats by clinically identifying individual animals for treatment. Vet. Res. 33(5):509-529.http://dx.doi.org/10.1051/vetres:2002036.PMid:12387487.

Vatta A.F., Letty B.A., van der Linde M.J., van Wijk E.F., Hansen J.W. \& Krecek R.C. 2001. Testing for clinical anaemia caused by Haemonchus spp. in goats farmed under resource-poor conditions in South Africa using an eye colour chart developed for sheep. Vet. Parasitol. 99(1):1-14. http://dx.doi. org/10.1016/S0304-4017(01)00446-0. PMid:11445151.

Vatta A.F., Waller J.P., Githiori B.J. \& Medley F.G. 2009. The potential to control Haemonchus contortus in indigenous South African goats with copper oxide wire particles. Vet. Parasitol. 162(3/4):306-313. http://dx.doi. org/10.1016/j.vetpar.2009.03.005. PMid:19346076.
Veríssimo C.J., Niciura S.C., Alberti A.L., Rodrigues C.F., Barbosa C.M., Chiebao D.P., Cardoso D., Silva G.S., Pereira J.R., Margatho L.F., Costa R.L., Nardon R.F., Ueno T.E., Curci V.C. \& Molento M.B. 2012. Multidrug and multispecies resistance in sheep flocks from Sao Paulo state, Brazil. Vet. Parasitol. 187(1/2):209-216. http://dx.doi.org/10.1016/j.vetpar.2012.01.013. PMid:22341829.

Vlaminck J., Borloo J., Vercruysse J., Geldhof P. \& Claerebout E. 2015. Vaccination of calves against Cooperia oncophora with a double-domain activation-associated secreted protein reduces parasite egg output and pasture contamination. Int. J. Parasitol. 45(4):209-213. http://dx.doi. org/10.1016/j.ijpara.2014.11.001. PMid:25513963.

Waller P.J. 2006. Sustainable nematode parasite control strategies for ruminant livestock by grazing management and biological control. Anim. Feed Sci. Technol. 126(3/4):277-289. http://dx.doi.org/10.1016/j. anifeedsci.2005.08.007.

Whitlock H.V. 1948. Some modifications of the McMaster helminth egg-counting technique apparatus. J. Council Sci. Ind. Res., Australia, 21:177-180 